\title{
Effect Of Earnings Management On Earnings Predictability In Information Signaling Perspective
}

\author{
Alex Johanes Simamora \\ Independent Researcher Yogyakarta \\ Email: alexjohanessimamora@gmail.com
}

\begin{abstract}
This research is aimed to examine (1) effect of discretionary and innate accrual on earnings predictability (2) effect of market share and financial health on relationship between real earnings management and earnings predictability. This research use manufacture firms listed in Indonesian Stock Exchange 2003-2015 as research sample, with 2013-2014 as research period. Accrual earnings management is measured by discretionary and innate abnormal accrual. Real earnings management is measured by aggregate of abnormal cash flow of operation, abnormal production, abnormal discretionary expenses. As expected, discretionary accrual as opportunist act does not support earnings predictability, while innate accrual as information signaling of business model improves earnings predictability. Real earnings management as information signaling of market share and financial health improves earnings predictability as well. In general, earnings management as information signaling is more likely to communicate condition of firm and leads to informativeness of earnings.
\end{abstract}

Abstrak: Penelitian ini bertujuan untuk menguji (1) pengaruh akrual diskresioner dan innate terhadap prediktabilitas laba. (2) pengaruh pangsa pasar dan kesehatan keuangan terhadap hubungan antara manajemen laba riil dengan prediktabilitas. Penelitian ini menggunakan perusahaan manufaktur yang terdaftar di bursa efek Indonesia 2003-2015 sebagai sampel, dengan periode penelitian 2013-2014. Manajemen laba akrual diukur dengan akrual abnormal diskresioner dan innate. Manajemen laba riil diukur dengan agregat arus kas abnormal, produksi abnormal, dan beban diskresioner abnormal. Sesuai prediksi, akrual diskresioner tidak meningkatkan prediktabilitas laba, sedangkan akrual innate sebagai sinyal informasi model bisnis meningkatkan prediktabilitas laba. Manajemen laba riil sebagai sinyal informasi pangsa pasar dan kesehatan keuangan juga meningkatkan prediktabilitas laba. Secara umum, manajemen laba sebagai pensinyalan informasi cenderung mengkomunikasikan kondisi perusahaan dan menuju pada laba yang informatif.

Keywords: Earnings Management, Earnings Predictability, Information Signaling

\section{INTRODUCTION}

Earnings are the most vital information which demonstrates the financial stability and strength of any firm (Tabassum et al., 2015). It refers to the bottom line item of income statement which exhibits how firm is financially beneficial and adding value to the shareholder's wealth as well as to predict future earnings. As earnings are the key to attain specific prediction of future earnings (Tabassum et al., 2015), management uses various techniques and strategies which are legal and sometimes illegal to achieve specific earning goals. This phenomenon is called earnings management. 
Earnings management can be classified into two categories, which are accruals earnings management (hereafter AEM) and real earnings management (hereafter REM). AEM means to manipulate the earnings through the utilization of accounting principles provided by GAAP, whereas REM means to accelerate earnings by changing some business activities (Roychowdhury, 2006). AEM is not accomplished by changing the underlying operating activities of the firm, but through the choice of accounting methods used to represent those activities, while REM involves changing the firm's underlying operations in an effort to boost current-period earnings (Gunny, 2010). Existences of AEM have been examined in previous researches, such as in pre and post-IFRS adoption in China (Ho et al., 2015) and in CEO debt (Dhole et al., 2016).

It is important to examine earnings management. Enron have been bankrupt in 2002 for earnings manipulation and covering financial problems and losses (Shirur, 2011). Enron case is a picture to describe existence of earnings management and its bad impact to the firm. Enron case leads to formulating of Sarbanes-Oxley Act (SOX). SOX is a set of business ethics, includes improvement of role of auditor, to reduce earnings management (Koh et al., 2008). Post SOX period, there is reducing of accounting fraudulent to beating or meeting analyst forecast and, at the same time, increasing of REM (Koh et al., 2008; Ho et al., 2015). There are evidences about existences of REM (Roychowdhury, 2006; Cohen et al., 2008).

In terms of earnings prediction, earnings management have effect on future earnings. REM have negative effect on future earnings (Cohen and Zarowin, 2010; Tabassum et al., 2014; Filip et al., 2015; Leggett et al., 2016; Vorst, 2016). Vorst (2016) found that REM, trough discretionary investments cutting, have effect on lower future performance because discretionary investments cutting leads to opportunity lost of investment in the future. Filip et al. (2015) found that REM, trough avoidance of impairment losses recognition, decreases future growth opportunity. REM leads to bigger real economic cost (Leggett et al., 2016) and create problems in the future (Tabassum et al., 2014). Cohen and Zarowin (2010) found performance decreasing after seasoned equity offerings for firms that engaged in REM. Bhojraj et al. (2009) show that firms that beat analyst forecasts by using REM and AEM have worse operating performance and stock market performance in the subsequent three years than firms that miss analyst forecasts without earnings management. Altamuro et al. (2005) found that early recognition of revenues, in terms of managing earnings, have low relationship between earnings and cash flow. It shows that earnings management decreases future earnings prediction as well as current earnings predictability.

Earnings management could be signaling information to earnings forecasting as well. Gunny (2010) found that REM have positive effect on future earnings. Vorst (2016) found that suspect firms engaged in REM (firms that meet or beat zero earnings) weakens negative effect of REM, trough discretionary investments cutting, on future earnings. Contrast with opportunist concept, REM could be a signal of firm's ability to generate better earnings in the future (Gunny, 2010). Siregar and Utama (2009) found evidences that AEM in Indonesia is not opportunist but efficient act. Rezaei and Roshani (2012) found that earnings management in Iran is efficient purpose as well. It shows that AEM increases future earnings prediction as well as earnings predictability.

There are inconsistencies of previous researches about effect of earnings management related to earnings prediction. These inconsistencies happen because previous research did not distinguish earnings management as opportunist act or 
information signaling. Jiraporn et al. (2008) found that discretionary accrual (proxy of AEM) in high-growth firms have higher pricing than low-growth firms. Gunny (2010) and Vorst (2016) have included information of meet or beat zero earnings on analysis of REM on future earnings. The results shows that meet or beat zero earnings could be information signaling of REM. Gunny and Zhang (2014) found that firms manage earnings to meet analyst forecasts to signal superior future performance. Previous researches do not include firm's condition that shown trough earnings management practices that could be information signaling to improve future performance.

In Indonesia, researches of earnings management are significant research because it have contribution of 18 percent of all accounting and finance research in National Symposium of Accounting as well as of 45.7 percent of all published research in big five accounting journal (Jurnal Akuntansi dan Auditing Indonesia, Jurnal Akuntansi, Jurnal Riset Akuntansi Indonesia, Akuntabilitas, Jurnal Akuntansi dan Keuangan Indonesia [Indonesian Journal of Accounting and Auditing, Journal of Accountancy, Indonesian Journal of Accounting Research, Accountability, Indonesian Journal of Accounting and Finance]) from 2000 until 2009 (Suhardianto and Harymawan, 2011). There are many previous researches have inconsistent result because of unclear earnings management motivations (Suhardianto and Harymawan, 2011). This research will contribute to spread of earnings management motivations as information signaling.

This research will examine effect of earnings management as information signaling on earnings predictability. In terms of AEM, this research will use innate abnormal accruals as information signaling of AEM. Francis et al. (2005) introduce innate abnormal accruals as accrual management caused by business model. Innate accruals (accrual management based on business model) increases earnings quality (Francis et al., 2005), and further, it could reducing information risk and cost of equity capital (Francis et al., 2004).

In terms of REM, this research will examine market share and financial health as information signaling of REM to increases earnings predictability. Zang (2012) and Abernathy et al. (2014) found that the higher market share and the healthier financial condition will leads to higher REM. Zang (2012) shows there are costs related to REM. Firms must have competitive advantage in its industry position and have healthy financial condition (Zang, 2012; Abernathy et al., 2014). Zang (2012) stated that since REM is a departure from optimal operational decisions, it can be particularly costly for firms that face intense competition in the industry. Therefore, managers in firms who have a lower percentage of industry market share may perceive REM as more costly because it can further erode their status within the industry (Abernathy et al., 2014). For a firm in poor financial health, the marginal cost of deviating from optimal business strategies is likely to be high (Zang, 2012). In this case, management might perceive real activities manipulation as relatively costly because their primary goal is to improve operations (Abernathy et al., 2014). REM leads to bigger real economic cost (Leggett et al., 2016) if only firms have lower market share and bad financial health. The aims of this research are (1) to examine effect of discretionary and innate abnormal accruals on earnings predictability (2) to examine effect of market share and financial health on relationship between REM and earnings predictability. 


\section{THEORETICAL REVIEW}

Agency Theory. Jensen and Meckling (1976) define agency theory as a contract between one or more parties (principal) that bind the other party (the agent) to carry out management of firm based on interests of principal, including the delegation of decision making authority to the agent. The main issue of agency theory is agency conflict. Agency conflict is come from conflict of interest between owners, as a principal, and management, as an agent. Owners have interest to maximize their wealth as well as management.

In terms of earnings information, agency conflict leads to dysfunctional behavior of management, such as earnings management. Earnings management usually refers to the efforts of firm managers or executives to manipulate the earnings figures in financial reporting (Tangjitprom, 2012). Earnings management could be bigger because of information asymmetric. Management have more information and know better about firm's condition compares to owners. This point of view leads to earnings management as opportunist act of management based on information asymmetric for their own-interest. This research will examine earnings management as information signaling to communicate firm's business model, market share and financial health.

Earnings Management as Information Signaling. There are two ways to understands earnings management. First, earnings management as management opportunist behavior in maximizes their utilities in terms of face contract of compensation, debt, and political cost (Scott, 2011). Second, earnings management as efficient contract perspective, which is earnings management gives management a flexibility to protect themselves and firm in terms of anticipates unexpected events for benefits of related parties (Scott, 2011).

In terms of AEM, managerial discretion improves the ability of earnings to reflect economic value. There is evidence of pervasive income smoothing, which improves the persistence and predictability of reported earnings. Subrmanyam (1996) found that managerial accrual discretion improves the ability of earnings to reflect economic value as well as help predict future cash flows, earnings, and dividends. Subramanyam (1996) finds evidence consistent with this hypothesis, suggests that discretionary accruals do add informational content to earnings. Lipe (1990) suggests that earnings management is technique that reduces earnings variability, and have advantage for stockholders to reduces uncertainty and increases predictability of future earnings. Innate accruals (accrual management based on business model) increases earnings quality (Francis et al., 2005), and further, it could reducing information risk and cost of equity capital (Francis et al., 2004), and increases firm value (Gaio and Raposo, 2011). Al-Attar et al. (2008) found that abnormal accrual could predict future cash flow and suggests that abnormal accruals are not merely the products of noise in the accruals-estimation process. In this case, managers will use earnings management to communicate some private information to the public, in order to get result in the improvement of firm value (Tangjitprom, 2012). Siregar and Utama (2009); Rezaei and Roshani (2012) found evidences that accrual earnings management as efficient purpose. Liu (2016) found that there is positive relationship between earnings management, both accrual and real earnings management, and economic value added in Association of Southeast Asian Nations (ASEAN).

In terms of REM, abnormal activities improve the ability of earnings to reflect economic value as well. Herbohn et al. (2010) suggest that management signal their expectations about an improvement (deterioration) in future firm performance via 
decreases (increases) in unrecognized deferred tax assets (losses). Further, Herbohn et al. (2010) found evidence that management use their judgment to report useful, valuerelevant information about future profitability of the firm. Gunny (2010) found that REM have positive effect on future earnings. There are two arguments of Gunny (2010), which are, first, the act of just meeting the benchmark by engaging in REM may provide benefits to the firm that enables better performance in the future, and second, the positive association between just meeting earnings benchmarks by engaging in REM and future performance is as well as consistent with signaling managerial competence or future firm performance. Vorst (2016) found that suspect firms of REM (firms that meet earnings) weakens negative effect of REM, trough discretionary investments cutting, on future earnings. Contrast with opportunist concept, REM could be a signal of firm's ability to generate better earnings in the future (Gunny, 2010).

As information signaling, earnings management practices have to be followed by some factors, in order to distinguish earnings management as opportunist act or information signaling one. Distinguish of abnormal accruals into discretionary and innate accruals (Francis et al., 2005) could be done to see AEM as opportunist act or information signaling. Meet or beat earnings benchmark as well as factor that could picture REM as information signaling. The act of just meeting the benchmark by engaging in REM may provide benefits to the firm that enables better performance in the future (Gunny, 2010) and could weakens negative effect of real earnings management, trough discretionary investments cutting, on future earnings (Vorst, 2016). Gunny and Zhang (2014) found that firms manage earnings to meet analyst forecasts to signal superior future performance.

Hypotheses. As opportunist act, earnings management is done to covers bad firm's condition. Cohen et al. (2011) found evidence that indicates management use warranty accruals to manage earnings opportunistically to meet earnings targets. Further, Cohen et al. (2011) find that the stock market recognizes the understatement of warranty liabilities of firms that managed earnings, not as information about firms' future performance and liability. Irani and Oesch (2016) suggests that managers use REM to enhance short-term performance in response to analyst pressure. Markarian and Santolo (2014) study theoretically the effect of product market competition on the incentives to engage in earnings manipulation, and shows how manipulating earnings is particularly rewarding in more competitive markets since the boost in market value of reporting good earnings is especially important. Objective of manipulating earnings is to cover market disadvantages of firms. Another opportunist earnings management is to cover bad performance around seasoned equity offering (SEO) to boost up share price (Kothari et al., 2016). Fisher et al. (2016) found that AEM prior to bankruptcy reduces the likelihood of plan confirmation and emergence of reorganization plan will be confirmed by a bankruptcy court.

Opportunist earnings management, both AEM and REM, have negative effect to future performance, firm value and share price. Opportunist earnings management could be done in order to fulfill bonus scheme or debt covenant (Scott, 2011). Earnings management responds by lowering share prices and corporate market value (Gill et al., 2013). Athanasakou et al. (2011) found that stock market gives lower rewards for firm that achieve analyst earnings expectation trough earnings management than trough genuine earnings forecast guidance. Nuryaman (2013) stated that AEM have negative effect on share price because earnings management practices can reduce the credibility of accounting information. Farooqi et al. (2014) stated REM reduces firm value, especially in 
industrially diversified firms. Fisher et al. (2016) stated management of earnings destroys economic value by making the emergence firms from bankruptcy looks like survival firms. REM will decreases future performance by opportunity lost of investment (Vorst, 2016) and future growth (Filip et al., 2015), bigger real economic cost (Leggett et al., 2016), destroys innovation strategy (Hwang et al., 2014), and create problems in the future (Tabassum et al., 2014). Cohen and Zarowin (2010) found performance decreasing after seasoned equity offerings for firms that engaged to REM.

As information signaling, earnings management improves the ability of earnings to reflect economic value, and have positive effect on future performance and firm value. Discretionary accruals help predict future cash flows, earnings, and dividends (Subrmanyam, 1996) because earnings management is technique that reduces earnings variability and have advantage for stockholders to reduces uncertainty (Lipe, 1990). AlAttar et al. (2008) suggests that abnormal accruals are not merely the products of noise in the accruals-estimation process.

Herbohn et al. (2010) suggest that management signal their expectations about an improvement (deterioration) in future firm performance via decreases (increases) in unrecognized deferred tax assets (losses). The act of just meeting the benchmark by engaging in REM may provide benefits to the firm that signaling managerial competence or future firm performance (Gunny, 2010; Gunny and Zhang, 2014; Vorst 2016). Eldenburg et al. (2011) found that REM related to pay-for-performance incentives leads to good operational decisions

In the other hand, there is contrast result between Gunny (2010); Gunny and Zhang (2014); Vorst (2016) stated that firms manage earnings to meet earnings benchmark to signal superior future performance, with Bhojraj et al. (2009) which stated that firms that beat analyst forecasts by using AEM and REM have worse operating performance and stock market performance in the subsequent three years. Cruz and Luiz (2015) stated that there is no association between both AEM and REM with stock return.

As information signaling, earnings management practices have to be followed by some factors, in order to distinguish earnings management as opportunist act or information signaling one. In order to distinguish earnings management as opportunist act or information signaling, analysis of earnings management could use fundamental factors as well, which is fundamental factors, such as innate factors (Francis et al., 2005), bankruptcy risk (Al-Attar et al., 2008), fundamental risk (Chen et al., 2008), managerial competences (Gunny, 2010) or performance incentives (Eldenburg et al., 2011). If abnormal accrual is not based on business model, then it is accrual earnings management as opportunist act.

This research will use discretionary abnormal accruals as opportunist act and innate abnormal accruals as information signaling of AEM based on Francis et al., (2005). For example, discretionary of decreasing of allowance of bad debt is not based on business condition then there will be possibility for earnings increasing in bonuses purpose for management. It shows opportunist act and will not support earnings predictability. In the other hand, discretionary of decreasing of allowance of bad debt based on business condition that shows customers have good payment profiles as information signaling and increases earnings predictability.

H1a: Discretionary abnormal accruals have no effect on earnings predictability

H1b: Innate abnormal accruals have positive effect on earnings predictability 
This research will use market share and financial health as information signaling of REM. High market share will reduce bankruptcy risk and increases firms' performance (Opler and Titman, 1994) and stock market value (Blundell et al., 1999). Zang (2012) shows that market share is cost of REM. Market share show the position and advantage of competition of industry. Zang (2012) stated that since REM is a departure from optimal operational decisions, it can be particularly costly for firms that face intense competition in the industry. Therefore, managers in firms who have a lower percentage of industry market share may perceive REM as more costly because it can further erode their status within the industry (Abernathy et al., 2014). Disadvantage of market position leads to opportunist REM (Markarian and Santolo, 2014). It shows that firms engaging in REM without high market share will leads to opportunist earnings management and decreases future earnings. Firms that have high market share means have low cost of REM (Zang 2012) and low cost of economic value, further, will lead to high future earnings. REM, as information signaling, communicate management competences (Gunny, 2010), such as high market share. For example, firms engage in REM trough over sales and over production activities shows that firms have ability to make high sales of product because of high market share, while cutting of RandD or advertisement expenses (expenses that support level of sales) have confidence in high sales of product because of high market share.

H2: REM have positive effect on earnings predictability, if market share is high

Healthier financial condition of firms leads to high performance (Opler and Titman, 1994) and high stock market value (Garlappi and Yan, 2011). Zang (2012) shows that financial health is cost of REM. High bankruptcy risk leads to opportunist earnings management (Al-Attar et al., 2008; Fisher et al., 2016). For a firm in poor financial health, the marginal cost of deviating from optimal business strategies is likely to be high (Zang, 2012). In this case, management might perceive REM as relatively costly because their primary goal is to improve operations (Abernathy et al., 2014). REM, as information signaling, communicate management competences (Gunny, 2010), such as healthy financial condition. For example, firms engage in REM trough over production activities shows that firms have good financial health to invest in production activities, while cutting of RandD or advertisement expenses (expenses that support level of sales and production). H3: REM have positive effect on earnings predictability, if financial health is high

Research's Framework. Based on hypotheses development, research framework is as followed.

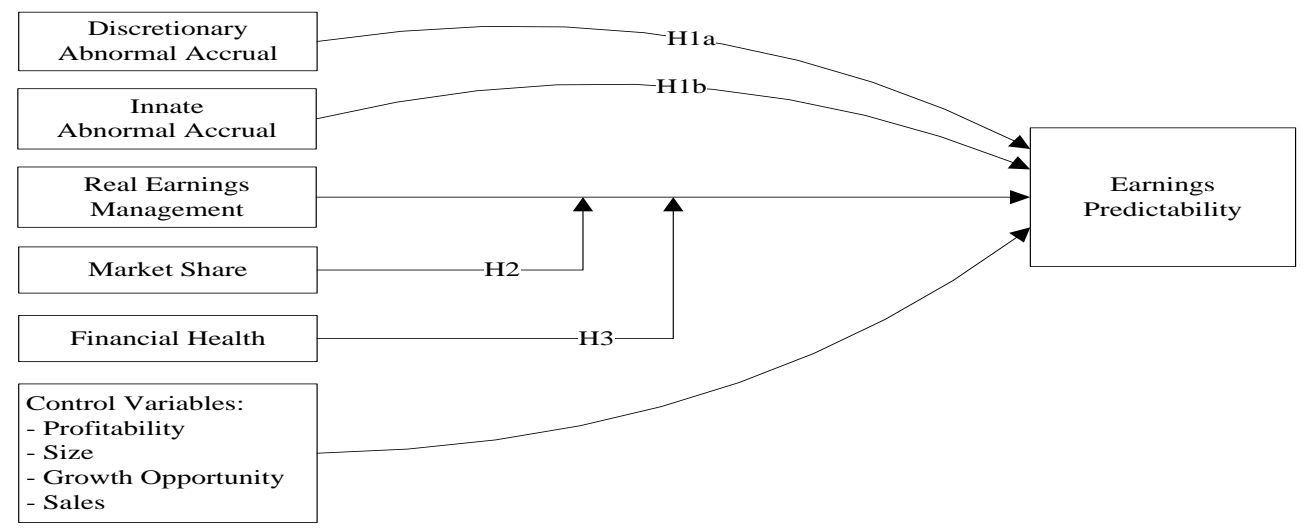

Figure 1. Research's Framework

Source: hypotheses development and previous researches 
In this research, dependent variable is earnings predictability. Independent variables are AEM and REM. Moderating variables are market share and financial health; while profitability, size, growth opportunity, and sales are the control variables.

\section{METHOD}

Research Sample. Population of research is listed firms in Indonesian Stock Exchange. In 2013-2014, Asian Development Bank (2016) have reported that Indonesian Stock Exchange have the second lowest, after Vietnam, corporate governance score of six countries of ASEAN Capital Market Forum. Liu (2016) infer that the firms in ASEAN nations have operated in environments where government policies were lacking and the market structure was underdeveloped and leads to higher earnings management activities. In addition, Indonesia have low disclosures of right of shareholders and other stakeholders as well as lack of transparency (Asian Development Bank, 2016). It means that Indonesia still have lack of corporate governance in business practices and high asymmetric information and will leads to real earnings management practices. Meanwhile, Indonesian Stock Exchange have potential investor, with its largest population among ASEAN countries, and growing firms (USAID, 2013). Further, Indonesian Stock Exchange is one of the most sensitive stock exchange in ASEAN to international financial market information (USAID, 2013). It is important to see Indonesian listed firms financial reporting with lack of transparency, in the same time having potential capital market.

Research sample is manufacture firms listed in Indonesian Stock Exchange 20032015. Research period is 2013-2014, with the use of data 2003-2015 (period t-10 until $\mathrm{t}+1$ ). In Indonesia, it is important to examine business practices in manufacture firms, because manufacture industry have the biggest contribution to national economic for last 20 years (BPS, 2015) as well as to avoid industry effect in earnings management practices. Total research sample is 125 manufacture firms. Sample selection process can be seen in Table 1.

Table 1. Research Sample

\begin{tabular}{lcc}
\hline & Firm & Firm-Year (2013-2014) \\
\cline { 2 - 3 } Manufacture firms listed in Indonesian Stock Exchange & 106 & 212 \\
2003-2015 in a row & & \\
Less: incomplete data $\quad(3)$ & $(6)$ \\
$\quad$ change financial statement period & $(4)$ & $(8)$ \\
Total sample & 99 & 198 \\
\hline
\end{tabular}

Source: Indonesian Stock Exchange

Research Variables. Dependent variable is earnings predictability. Earnings predictability is ability of earnings to predict itself (Lipe, 1990). Earnings predictability is measured by model as follow (Francis et al., 2004):

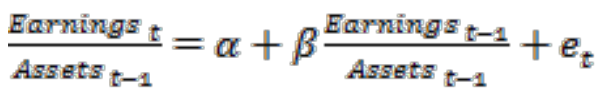

Earnings predictability shows by percentile rank of square root variance value of $e_{t}$ $\left[\sqrt{\sigma^{2}\left(e_{t}\right)}\right]$ (Francis et al., 2004) in equation (1). Value of $\mathrm{e}_{\mathrm{t}}$ calculated by autoregressive 
model for past ten years (for time series period t-9 until period t) for each firm-years (Francis et al., 2004). The higher $\left[\sqrt{\sigma^{2}\left(e_{t}\right)}\right]$, the higher earnings predictability is.

Independent variable is AEM and REM. AEM is measured by abnormal accruals with Dechow-Dichev model modified by Francis et al. (2005) is as follow:

$\frac{T C A_{t}}{\text { Assets }_{t}}=a+b 1 \frac{\text { CFO }_{t-1}}{\text { Assets }_{t}}+b 2 \frac{\text { CFO }_{t}}{\text { Assets }_{t}}+b 3 \frac{\text { CFO }_{t+1}}{\text { Assets }_{t}}+b 4 \frac{\text { PPE }_{t}}{\text { Assets }_{\mathrm{t}}}+b 3 \frac{\text { Sales }_{\mathrm{t}}}{\text { Assets }_{\mathrm{t}}}+e_{t}$

Absolute value of $e_{t}$ in equation (2) is abnormal accruals. To distinguish AEM as opportunist act and information signaling, then model that will be used as follow (Francis et al., 2005):

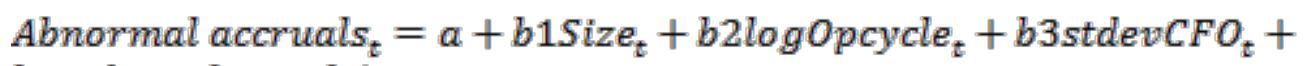
b4stdevSales ${ }_{t}+b 5$ NegEarn $_{t}+e_{t}$

Value of $e_{t}$ in equation (3) is discretionary accruals as opportunist AEM. Estimation of coefficient equation (3) will be used to calculated innate accrual (Francis etal., 2005):

Innate accrual $_{t}=$

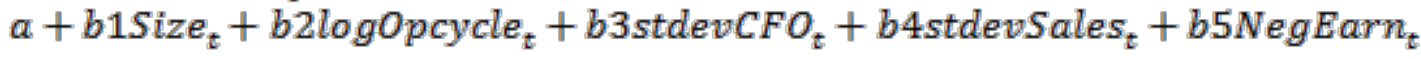

Higher innate accrual shows higher AEM as information signaling.

Activities that will be occurred to detect REM are sales manipulation, over production, and discretionary expenses cutting. In order to estimate sales manipulation activity, over production, and discretionary expenses cutting equation that will be used as follow (Roychowdhury, 2006):

$$
\begin{aligned}
& \frac{\text { CFO }_{t}}{\text { Assets }_{t-1}}=a+b 0 \frac{1}{\text { Assets }_{t-1}}+b 1 \frac{\text { Sales }_{t}}{\text { Assets }_{t-1}}+b 2 \frac{\Delta \text { Sales }_{t}}{\text { Assets }_{t-1}}+e_{t} \\
& \frac{\text { Production }_{t}}{\text { Assets }_{t-1}}=a+b 0 \frac{1}{\text { Assets }_{t-1}}+b 1 \frac{\text { Sales }_{t}}{\text { Assets }_{t-1}}+b 2 \frac{\Delta \text { Sales }_{t}}{\text { Assets }_{t-1}}+b 3 \frac{\Delta \text { Sales }_{t-1}}{\text { Assets }_{t-1}}+e_{t} \\
& \frac{\text { Discretionary expenses }_{t}}{\text { Assets }}=a+b 0 \frac{1}{\text { Assets }_{t-1}}+b 1 \frac{\text { Sales }_{t}}{\text { Assets }_{t-1}}+e_{t}
\end{aligned}
$$

Indication of REM is negative value of abnormal CFO (ABCFO), positive value of abnormal PROD (ABPROD), and negative value of abnormal DISEXP (ABDISEXP) (Cohen et al., 2008). Abnormal CFO is value of $e_{t}$ from the equation (5). Abnormal PROD is value of $e_{t}$ from the equation (6). Abnormal DISEXP is value of $e_{t}$ from the equation (7).

If management of a firm is engaged with one type of REM activity, then management will be engaged as well as the other type of REM activity (Cohen et al., 2008; Chi et al., 2011). This research will use aggregate of three types of REM activities as well as comprehensive measurement of REM is as follow (Cohen et al., 2008; Chi et al., 2011): 


\section{REM $=-$ standardize abnormal CFO + standardize abnormal PROD - standardize abnormal DISEXP}

Real earnings management occurred by positive value of REM (Chi et al., 2011).

Moderating variables are market share and financial health. Market share show the position and competition of industry. Zang (2012) stated that since REM is a departure from optimal operational decisions, it can be particularly costly for firms that face intense competition in the industry. Therefore, managers in firms who have a lower percentage of industry market share may perceive REM as more costly because it can further erode their status within the industry (Abernathy et al., 2014). Market share is calculated by total sales of firm divided by total sales of industry group (within three digits of industry code) at the beginning period (Zang, 2012; Abernathy et al., 2014).

For a firm in poor financial health, the marginal cost of deviating from optimal business strategies is likely to be high (Zang, 2012). In this case, management might perceive real activities manipulation as relatively costly because their primary goal is to improve operations (Abernathy et al., 2014). Financial health is measured by z score of Altman (1968) at the beginning period. The higher z score, the healthier a firm. Z score of Altman (1968) as follow:

$z=1.2 X 1+1.4 X 2+3.3 X 3+0.6 X 4+0.999 X 5$

\section{The higher $\mathrm{z}$ score, the healthier a firm.}

Control variables are profitability, size, growth opportunity, and sales. Profitability, size, and growth opportunities are used to control whether abnormal activities came from business condition or indication of real earnings management (Roychowdhury, 2006). Profitability is measured by return on assets (ROA) (net income before extra ordinary items divided by lagged total assets). Size is measured by logarithm of total assets period $\mathrm{t}-1$. Growth opportunity is measured by market value of equity divided by total assets (MVA) period t-1. Sales used as control variables because it is related to market share. Sales measured by total sales divided by lagged total assets. ROA and MVA have positive effect on future earnings (Gunny, 2010; Liow, 2010; Muzir, 2011), so it can improves prediction earnings as well as improve earnings predictability. The bigger size and sales shows the bigger complexity in earnings prediction (Jennings et al., 2015), so it will reduce earnings predictability.

Analysis Method. Descriptive statistics provide a description of data that can be seen from the mean value, standard deviation, maximum and minimum. Classical assumption testing includes normality, multicollinearity, autocorrelation, and heteroscedasticity. This research will use multiple regression as hypotheses testing. Regression model is as followed:

$$
\begin{aligned}
& E P_{t}=\alpha+\beta_{1} D A_{t}+\beta_{2} I A_{t}+\beta_{3} R M_{t}+\beta_{4} M S_{t-1} R E M_{t}+\beta_{5} z_{t-1} R E M_{t}+\beta_{6} M S_{t-1}+ \\
& \beta_{7} z_{t-1}+\beta_{8} R O A_{t}+\beta_{9} \text { Size }_{t-1}+\beta_{10} \text { MVA }_{t-1}+\beta_{11} \text { Sales }_{t}+e
\end{aligned}
$$

All explanations of variables in equation (2) until (10) are as follow: 
Table 2.Variable Definition

\begin{tabular}{|c|c|}
\hline Variable & Definition \\
\hline $\mathrm{TCA}_{\mathrm{t}}$ & $\begin{array}{l}\text { Total current accrual period } t \text {, calculated by [net income }- \text { cash flow } \\
\text { form operation }+ \text { depreciation and amortization] divided by assets } \\
\text { period } t\end{array}$ \\
\hline $\mathrm{CFO}_{\mathrm{t}-1}$ & Cash flow from operation period $\mathrm{t}-1$ \\
\hline $\mathrm{CFO}_{\mathrm{t}}$ & Cash flow from operation period $t$ \\
\hline $\mathrm{CFO}_{\mathrm{t}+1}$ & Cash flow from operation period $t+1$ \\
\hline $\mathrm{PPE}_{\mathrm{t}}$ & Property, plant, and equipment period t \\
\hline Sales $_{t}$ & Sales period $\mathrm{t}$ \\
\hline Size $_{t}$ & Logarithm of total assets period t \\
\hline $\operatorname{logOpCycle} e_{t-1}$ & $\begin{array}{l}\text { Logarithm of operating cycle period t. Operating cycle calculated by } \\
\text { [days of outstanding receivable }+ \text { days of inventory turnover] }\end{array}$ \\
\hline stdevCFO $_{t}$ & $\begin{array}{l}\text { Standard deviation of cash flow from operation for past ten years } \\
\text { [period t-9 until period } t \text { ] }\end{array}$ \\
\hline stdevSales $_{t}$ & $\begin{array}{l}\text { Standard deviation of sales for past ten years [period t-9 until period } \\
\text { t] }\end{array}$ \\
\hline NegEarn $_{t}$ & $\begin{array}{l}\text { Number of years for past ten years, where net income of firm below } \\
\text { zero }\end{array}$ \\
\hline$\Delta$ Sales $_{\mathrm{t}}$ & Change of sales period $t$ \\
\hline Production $_{\mathrm{t}}$ & $\begin{array}{l}\text { [Inventory period } t \text { minus inventory period } t-1 \text { plus cost of good sold } \\
\text { period } t \text { ] divided by assets period } t\end{array}$ \\
\hline$\Delta$ Sales $_{\mathrm{t}-1}$ & Change of sales period $t-1$ \\
\hline Discretionary Expenses $_{t}$ & $\begin{array}{l}\text { Sales and General Administration Expenses period t plus Research } \\
\text { and Development Expenses period t }\end{array}$ \\
\hline $\mathrm{X} 1$ & Working capital divided by total assets \\
\hline $\mathrm{X} 2$ & Retained earnings divided by total assets \\
\hline X3 & Earnings before interest and tax divided by total assets \\
\hline $\mathrm{X} 4$ & Market value of equity divided by total liabilities \\
\hline $\mathrm{X} 5$ & Sales divided by total assets \\
\hline $\mathrm{EP}_{\mathrm{t}}$ & Earnings predictability period t \\
\hline $\mathrm{DA}_{\mathrm{t}}$ & Discretionary abnormal accruals period t \\
\hline $\mathrm{IA}_{\mathrm{t}}$ & Innate abnormal accruals period $t$ \\
\hline $\mathrm{REM}_{\mathrm{t}}$ & Real earnings management period $t$ \\
\hline $\mathrm{MS}_{\mathrm{t}-1} \mathrm{REM}_{\mathrm{t}}$ & Interaction between $\mathrm{MS}_{\mathrm{t}-1}$ and $\mathrm{REM}_{\mathrm{t}}$ \\
\hline $\mathrm{z}_{\mathrm{t}-1} \mathrm{REM}_{\mathrm{t}}$ & Interaction between $\mathrm{z}_{\mathrm{t}-1}$ and $\mathrm{REM}_{\mathrm{t}}$ \\
\hline $\mathrm{MS}_{\mathrm{t}-1}$ & Market share period t-1 (beginning of period t) \\
\hline $\mathrm{z}_{\mathrm{t}-1}$ & Financial health period t-1 (beginning of period t) \\
\hline $\mathrm{ROA}_{\mathrm{t}}$ & Return on assets period t \\
\hline Size $_{\mathrm{t}-1}$ & Size of firm period t-1(beginning of period t) \\
\hline $\mathrm{MVA}_{\mathrm{t}-1}$ & $\begin{array}{l}\text { Market value of equity to total assets period t-1(beginning of period } \\
\text { t) }\end{array}$ \\
\hline
\end{tabular}

Sources: previous researches

Table 3 shows that, on average, innate abnormal accrual (5.8706) higher than discretionary abnormal accrual (0.0000). This result shows that Indonesian manufacture firms more likely to use AEM as information signaling than opportunist act. It is consistent with Siregar and Utama (2009) that AEM in Indonesia is not opportunist but for efficient purposes. 


\section{RESULTS AND DISCUSSION}

\section{Descriptive Statistics}

Tabel 3. Descriptive Statistics

\begin{tabular}{llrrrr}
\hline & $\mathrm{N}$ & Minimum & Maximum & Mean & Standard Deviation \\
\hline EP & 198 & 0.00 & 1.00 & .4995 & 0.29232 \\
DA & 198 & -8.95679 & 236.24708 & 0.0000000 & 23.17432255 \\
IA & 198 & -7.68 & 11.14 & 5.8706 & 2.71384 \\
REM & 198 & -7.01 & 13.13 & 0.0000 & 2.34782 \\
MS x REM & 198 & -5.66 & 1.45 & -0.0523 & 0.70134 \\
Z x REM & 198 & -582.82 & 45.76 & -7.3079 & 47.32142 \\
MS & 198 & 0.00 & 0.91 & 0.1526 & 0.20597 \\
Z & 198 & -9.94 & 254.13 & 5.5635 & 18.54578 \\
SIZE & 198 & 10.98 & 14.33 & 12.2552 & 0.68863 \\
MVA & 198 & 0.00 & 15.62 & 1.2491 & 2.12061 \\
ROA & 198 & -0.35 & 2.65 & 0.0660 & 0.21774 \\
SALES & 198 & 0.03 & 5.02 & 1.1640 & 0.70680 \\
ABCFO & 198 & -1.04 & 0.56 & -0.1129 & 0.17238 \\
ABPROD & 198 & -2.07 & 0.27 & -0.1736 & 0.30747 \\
ABDISEXP & 198 & -1.43 & 0.59 & -0.1198 & 0.20796 \\
\hline
\end{tabular}

REM in Indonesia, on average, is dominated by discretionary expenses cutting activity (with level of abnormal discretionary expenses 0.1198). The lowest REM practice in Indonesia is overproduction activity (with level of abnormal discretionary expenses 0.1736). Result shows that manufacture firms in Indonesia are more likely to engage in REM trough cutting of discretionary expenses.

\section{Classical Assumption Analysis}

Table 4. Classical Assumption

\begin{tabular}{lll}
\hline Test & Result & Notes \\
\hline Jarque-Bera & Sig. Value $=0.175$ & Data is distributed normally \\
ARCH & Sig. Value $=0.109$ & Free of heterocedasticity problem \\
Serial Correlation LM & Sig. Value $=0.647$ & Free of autocorrelation problem \\
VIF & VIF $<10^{\mathrm{a}}$ & Free of multicollinearity problem \\
\hline a & Except for variable interaction between Z with REM; and variable Z; VIF $>10$. \\
b & Hartono (2010) stated that symptom of multicollinearity is happens in moderating \\
\multicolumn{2}{l}{$\begin{array}{l}\text { regression, and explain that coefficient of moderating effect variable does not } \\
\text { sensitive on change of independent variable. }\end{array}$} \\
\hline
\end{tabular}

Table 4 shows that significance value of Jarque-Bera is 0.175 (have no significant), means residual of this research distributed normally. Significance value of $A R C H$ is 0.109 (have no significant), means this research is free of heterocedasticity problem. Significant value of Serial Correlation LM is 0.647 (have no significant), means that this research is free of autocorrelation problem. This research have VIF below 10, means that this research o free of multicollinearity problem. The results indicate that this research have fulfill the classical assumption. 


\section{Hypotheses Analysis}

Table 5. Regression Test

\begin{tabular}{llll}
\hline Variable & Coefficient & Sig. & Notes \\
\hline DA & 0.000733 & 0.3924 & H1a accepted \\
IA & $0.016384^{* *}$ & 0.0466 & H1b accepted \\
REM & 0.013938 & 0.3389 & \\
MS x REM & $0.100271^{* *}$ & 0.0212 & H2 accepted \\
Z x REM & $0.003712^{* * *}$ & 0.0097 & H3 accepted \\
MS & $0.417438^{* * *}$ & 0.0018 & \\
Z & $0.009637^{* * *}$ & 0.0048 & \\
ROA & $0.160963^{*}$ & 0.0909 & \\
SIZE & $-0.212644^{* * *}$ & 0.0000 & \\
MVA & $0.045505^{* * *}$ & 0.0060 & \\
SALES & $-0.135574^{* * *}$ & 0.0013 & \\
Constant & $3.014732^{* * *}$ & 0.0000 & \\
\hline Adjusted R-squared & 0.137010 & & \\
F-statistic & $3.843280^{* * *}$ & & \\
*** Significant in 1 percent & & & \\
** Significant in 5 percent & & & \\
$*$ Significant in 10 percent & & & \\
\hline
\end{tabular}

Table 5 shows that $\mathrm{F}$ statistic significant in 1 percent, shows that all independent variables have effect on earnings predictability as well as fitness of regression model. Adjusted Rsquared have value 0.137010 , means all independent variables have power explanation to earnings predictability as 13.701 percent, while 86.299 power explanation of percent earnings predictability are other variables which are not including in this research.

Discretionary abnormal accrual have no significant effect (with significance value 0.3924) on earnings predictability. Innate abnormal accrual have positive significant effect (with significance value 0.0466, significant in 5 percent) on earnings predictability. As expected, it indicates that AEM as opportunist act does not support earnings predictability, while increasing of AEM as information signaling improves earnings predictability. AEM as opportunist act is done based on manager interest with no consideration of earnings quality to predict future earnings. AEM as information signaling is done based on based on business model of firm, so earnings management will reflect actual condition of firm and leads to higher earnings informativeness to predict future earnings.

Interaction between REM with market share have positive effect on earnings predictability. As expected, REM, as information signaling, communicates management competences, which is high market share that leads to high future earnings. REM have positive effect on earnings predictability, if market share is high. Information signaling of market share improves earnings predictability. REM, as information signaling, shows market share power of firm to improve higher earnings. With market share signaling, earnings will have higher predictability and help to predict future earnings.

Interaction between REM with financial health have positive effect on earnings predictability. As expected, REM, as information signaling, communicates management competences, which is high financial health that leads to high future earnings. Information signaling of financial health improves earnings predictability. REM have positive effect on earnings predictability, if financial health is high. REM, as information signaling, shows 
financial health of firm to improve higher earnings. With financial health signaling, earnings will have higher predictability and help to predict future earnings.

Additional Analysis. In order to analyze which REM activities that have information signaling, either information of market share or financial health, this research examined each activities of REM as well. Over sales activity (level of abnormal CFO), over production activity (level of abnormal production cost), and discretionary expenses cutting activity (level of abnormal discretionary expenses) are examined as information signaling, by measure its effect on earnings predictability, partially.

Table 6. Additional Test

\begin{tabular}{llll}
\hline Variable & $\begin{array}{l}\text { REM }=\text { ABCFO } \\
\text { Coefficient }\end{array}$ & $\begin{array}{l}\text { REM }=\text { ABPROD } \\
\text { Coefficient }\end{array}$ & $\begin{array}{l}\text { REM = ABDISEXP } \\
\text { Coefficient }\end{array}$ \\
\hline DA & 0.000557 & 0.001032 & 0.000201 \\
IA & $0.016845^{* *}$ & $0.017750^{* *}$ & $0.016096^{*}$ \\
REM & 0.067286 & $0.234452^{* *}$ & -0.030527 \\
MS x REM & $-1.788194^{* *}$ & $1.210589^{* * *}$ & -0.407677 \\
Z x REM & -0.021091 & 0.004284 & $-0.033507^{*}$ \\
MS & 0.155352 & $0.646068^{* * *}$ & $0.359833^{* *}$ \\
Z & -0.002626 & 0.003442 & $0.007075^{* *}$ \\
ROA & 0.147598 & $0.161161^{*}$ & 0.121003 \\
SIZE & $-0.161786^{* * *}$ & $-0.233638^{* * *}$ & $-0.189993^{* * *}$ \\
MVA & 0.024903 & $0.069161^{* * *}$ & -0.008573 \\
SALES & $-0.086716^{*}$ & $-0.069292^{* *}$ & $-0.104355^{* *}$ \\
Constant & $2.409060^{* * *}$ & $3.216586^{* * *}$ & $2.745999^{* * *}$ \\
\hline Adjusted R-squared & 0.069027 & 0.143069 & 0.088651 \\
F-statistic & $2.327880^{* *}$ & $3.990003^{* * *}$ & $2.742105^{* * *}$ \\
\hline *** Significant in 1 percent & & \\
** Significant in 5 percent & & \\
* Significant in 10 percent & & \\
\hline
\end{tabular}

Table 6 shows that interaction between market share with abnormal CFO have positive effect (coefficient value shows negative sign, since over sales measured by negative value of abnormal CFO) on earnings predictability, while interaction between financial health with abnormal CFO have no effect on earnings predictability. It indicates that over sales and activities are more likely to communicate information of good position of market share than information of financial health.

Interaction between market share with abnormal production have positive effect on earnings predictability, while interaction between financial health with abnormal production have no effect on earnings predictability. It indicates that over production activities are more likely to communicate information of good position of market share than information financial health.

Interaction between financial health with abnormal discretionary expenses have positive effect (coefficient value shows negative sign, since discretionary expenses cutting measured by negative value of abnormal discretionary expenses) on earnings predictability, while interaction between market share with abnormal discretionary expenses have no effect on earnings predictability. It indicates that discretionary expenses 
cutting activity are more likely to communicate information of good financial health than information of market share.

\section{CONCLUSION}

This research is aimed to examine (1) effect of discretionary and innate accrual on earnings predictability (2) effect of market share and financial health on relationship between REM and earnings predictability. As expected, discretionary accrual as opportunist act of AEM does not support earnings predictability, while innate accrual as information signaling of business model improves earnings predictability. REM as information signaling of market share and financial health improves earnings predictability as well. In general, earnings management as information signaling is more likely to communicate condition of firm and leads to informativeness of earnings.

To academics, this research have contribution as additional literature of earnings management as information signaling of business model, market share, and financial health. To financial statement user, this research have contribution as additional information that will leads to better economic decision making with analyzing of earnings management as information signaling of business model, market share, and financial health. To regulatory bodies, this research have implication as additional information to make regulation to improve earnings management as information signaling.

Limitation of this research is does not consider chance of downward REM as information signaling. Another limitation of this research is does not consider corporate governance as agency cost to control information signaling of earnings management, both AEM and REM.

\section{BIBLIOGRAPHY}

Abernathy, J.L., B. Beyer, and E.T. Rapley. (2014). "Earnings Management Constraints and Classification Shifting”. Journal of Business Finance \& Accounting 41 (56):600-626. DOI: https://doi.org/10.1111/jbfa.12076.

Al-Attar, A., S. Hussain, and L.Y. Zuo. (2008). "Earnings Quality, Bankruptcy Risk and Future Cash Flows". Accounting and Business Research 38(1), 5-20. DOI: https://doi.org/10.1080/00014788.2008.9663317.

Altamuro, J., A.L. Beatty, and J. Webber. (2005). “The Effects of Accelerated Revenue Recognition on Earnings Management and Earnings Informativeness: Evidence from SEC Staff Accounting Bulletin No. 101”. The Accounting Review 80 (2), 373-401.

Altman, E.I. (1968). "Financial Ratios, Discriminant Analysis and the Prediction of Corporate Bankruptcy”. The Journal of Finance 23(4), 589-609. DOI: https://doi.org/10.1111/j.1540-6261.1968.tb00843.x.

Asian Development Bank. (2016). ASEAN Corporate Governance Scorecard Country Reports and Assessments 2015. Philippines: Asian Development Bank.

Athanasakou, V., N.C. Strong, and M. Walker. (2011). “The Market Reward for Achieving Analyst Earnings Expectations: Does Managing Expectations or Earnings Matter?”. Journal of Business Finance \& Accounting 38(1-2), 58-94. DOI: https://doi.org/10.1111/j.1468-5957.2010.02219.x.

Badan Pusat Statistik [Statistics Bureau]. (2015). Perkembangan Indeks Produksi Industri Manufaktur Besar Dan Sedang 2013-3015 [Development of Production Index of 
Large and Medium Manufacture Industry 2013-2015]. Jakarta: Badan Pusat Statistik.

Bhojraj, S., P. Hribar, M. Picconi, and J. McInnis. (2009). "Making Sense of Cents: An Examination of Firms That Marginally Miss or Beat Analyst Forecasts". The Journal of Finance 64 (5):2361-88. DOI: https://doi.org/10.1111/j.1540-6261.2009.01503.x.

Blundell, R., R. Griffiths, and J. Van Reenen. (1999). "Market Share, Market Value and Innovation in a Panel of British Manufacturing Firms". Review of Economic Studies 66 (3), 529-54. DOI: https://doi.org/10.1111/1467-937X.00097.

Chen, L.H., D.S. Dhaliwal, and M.A. Trombley. (2008). "The Effect of Fundamental Risk on the Market Pricing of Accruals Quality”. Journal of Accounting, Auditing \& Finance 23 (4), 471-92. DOI: https://doi.org/10.2139/ssrn.954964.

Chi, W., L.L. Lisic, and M. Pevzner. (2011). "Is Enhanced Audit Quality Associated with Greater Real Earnings Management?”. Accounting Horizons 25 (2):315-35. DOI: https://doi.org/10.2308/acch-10025.

Cohen, D.A., M.N. Darrough, R. Huang, and T. Zach. (2011). "Warranty Reserve: Contingent Liability, Information Signal, or Earnings Management Tool?”. The Accounting Review, 86 (2), 569-604. DOI: https://doi.org/10.2308/accr.00000021.

Cohen, D.A., A. Dey, and T.Z. Lys. (2008). "Real and Accrual Based Earnings Management in the Pre and Post Sarbanes Oxley Periods". The Accounting Review 83 (3):757-87. DOI: https://doi.org/10.2308/accr.2008.83.3.757.

Cohen, D.A., and P. Zarowin. (2010). “Accrual-Based and Real Earnings Management Activities around Seasoned Equity Offerings". Journal of Accounting and Economics, 50 (1), 2-19. DOI: https://doi.org/10.1016/j.jacceco.2010.01.002.

Cruz, D., and A. Luiz. (2015). Earnings Management Choice: An Empirical Study on the Impact of Earnings Management on Stock Returns in DLSU Research Congress. Manila, Philippines: De La Salle University.

Dhole, S., H. Manchiraju, and I. Suk. (2016). "CEO Inside Debt and Earnings Management”. Journal of Accounting, Auditing \& Finance, 31 (4), 515-50.

Eldenburg, L.G., K.A. Gunny, K.W. Hee, and N. Soderstrom. (2011). "Earnings Management Using Real Activities: Evidence from Nonprofit Hospitals". The Accounting Review, 86 (5),1605-30. DOI: https://doi.org/10.2308/accr-10095.

Farooqi, J., O. Harris, and T. Ngo. (2014). "Corporate Diversification, Real Activities Manipulation, and Firm Value”. Journal of Multinational Financial Management 27 (October):130-51. DOI: https://doi.org/10.1016/j.mulfin.2014.06.010.

Filip, A., T. Jeanjean, and L. Paugam. (2015). "Using Real Activities to Avoid Goodwill Impairment Losses: Evidence and Effect on Future Performance". Journal of Business Finance \& Accounting 42(3-4), 515-54. DOI: https://doi.org/10.1111/jbfa.12107.

Fisher, T.C.G., I. Gavious, and J. Martel. (2016). Earnings Management and Firm Value in Chapter 11. Working Paper. University of Sydney, Australia, Ben-Gurion University of the Negev, Israel, ESSEC Business School, France.

Francis, J., R. LaFond, P. Olsson, and K. Schipper. (2005). "The Market Pricing of Accruals Quality”. Journal of Accounting and Economics 39(2), 295-327. DOI: https://doi.org/10.1016/j.jacceco.2004.06.003.

Francis, J., R. LaFond, P.M. Olsson, and K. Schipper. (2004). "Costs of Equity and Earnings Attributes". The Accounting Review 79(4), 967-1010. DOI: https://doi.org/10.2308/accr.2004.79.4.967. 
Gaio, C., and C. Raposo. (2011). "Earnings Quality and Firm Valuation: International Evidence". Accounting \& Finance 51 (2), 467-99. DOI: https://doi.org/10.1111/j.1467-629X.2010.00362.x.

Garlappi, L., and H. Yan. (2011). "Financial Distress and the Cross-Section of Equity Returns". The Journal of Finance 66(3),789-822. DOI: https://doi.org/10.1111/j.1540-6261.2011.01652.x.

Gill, A., N. Biger, H.S. Mand, and N. Mathur. (2013). "Earnings Management, Firm Performance, and the Value of Indian Manufacturing Firms". International Research Journal of Finance and Economics 116:120-32.

Gunny, K.A. (2010). “The Relation Between Earnings Management Using Real Activities Manipulation and Future Performance: Evidence from Meeting Earnings Benchmarks”. Contemporary Accounting Research 27(3), 855-88. DOI: https://doi.org/10.1111/j.1911-3846.2010.01029.x.

Gunny, K.A., and T.C. Zhang. (2014). "Do Managers Use Meeting Analyst Forecasts to Signal Private Information? Evidence from Patent Citations". Journal of Business Finance \& Accounting, 41(7-8), 950-73. DOI: https://doi.org/10.1111/jbfa.12082.

Hartono, J. (2010). Metodologi Penelitian Bisnis: Salah Kaprah Dan PengalamanPengalaman. [Business Research Methodology: Misinterpretations and Experiences]. Yogyakarta, Indonesia: BPFE UGM.

Herbohn, K., I. Tutticci, and P.S. Khor. (2010). "Changes in Unrecognised Deferred Tax Accruals from Carry-Forward Losses: Earnings Management or Signalling?”. Journal of Business Finance \& Accounting 37(7-8), 763-91. DOI: https://doi.org/10.1111/j.1468-5957.2010.02207.x.

Ho, L.J., Q. Liao, and M. Taylor. (2015). "Real and Accrual-Based Earnings Management in the Pre- and Post-IFRS Periods: Evidence from China”. Journal of International Financial Management \& Accounting, 26 (3), 294-335.

Hwang, N.C.R., J.R. Chiou, M.H.E. Hsueh, and C.C. Hsieh. (2014). How Does Earnings Management Affect Innovation Strategies of Firms?. Working Paper. California State University San Marcos, USA, National Cheng Kung University, Taiwan, National Changhua University of Education, Taiwan.

Irani, R.M., and D. Oesch. (2016). “Analyst Coverage and Real Earnings Management: Quasi-Experimental Evidence”. Journal of Financial and Quantitative Analysis, 51 (02), 589-627. DOI: https://doi.org/10.1017/S0022109016000156.

Jennings, J., H. Seo, and L. Tanlu. (2015). The Effect of Organizational Complexity on Earnings Forecasting Behavior. Working Paper. Washington University in St. Louis, NUS Business School, Northen University

Jensen, M.C., and W.H. Meckling. (1976). "Theory of the Firm: Managerial Behavior, Agency Costs and Ownership Structure”. Journal of Financial Economics, 3 (4), 305-60. DOI: https://doi.org/10.1016/0304-405X(76)90026-X.

Jiraporn, P., G.A. Miller, S.S. Yoon, and Y.S. Kim. (2008). "Is Earnings Management Opportunistic Or Beneficial?: An Agency Theory Perspective”. International Review of Financial Analysis, 17 (3), 622-34.

Koh, K., D.A. Matsumoto, and S. Rajgopal. (2008). "Meeting or Beating Analyst Expectations in the Post-Scandals World: Changes in Stock Market Rewards and Managerial Actions”. Contemporary Accounting Research, 25 (4),1067-98. DOI: https://doi.org/10.1506/car.25.4.5.

Kothari, S.P., N. Mizik, and S. Roychowdhury. (2016). “Managing for the Moment: The 
Role of Earnings Management via Real Activities versus Accruals in SEO Valuation". The Accounting Review, 91 (2), 559-86. DOI: https://doi.org/10.2308/accr-51153.

Leggett, D.M., L.M. Parsons, and A.L. Reitenga. (2015). "Real Earnings Management and Subsequent Operating Performance”. IUP Journal of Operations Management 15 (4), 7-32.

Liow, K.H. (2010). “Firm Value, Growth, Profitability and Capital Structure of Listed Real Estate Companies: An International Perspective”. Journal of Property Research, 27 (2),119-46. DOI: https://doi.org/10.1080/09599916.2010.500459.

Lipe, R. (1990). “The Relation between Stock Returns and Accounting Earnings Given Alternative Information”. The Accounting Review, 65 (1), 49-71.

Liu, Z.J. (2016). "Effect of Earnings Management on Economic Value Added: A CrossCountry Study”. South African Journal of Business Management, 47 (1), 29-36.

Markarian, G., and J. Santalo'. (2014). "Product Market Competition, Information and Earnings Management”. Journal of Business Finance \& Accounting, 41 (5-6), 57299. DOI: https://doi.org/10.1111/jbfa.12064.

Muzir, E. (2011). “Triangle Relationship among Firm Size, Capital Structure Choice and Financial Performance”. Journal of Management Research, 11 (2), 87-98.

Nuryaman. (2013). "The Influence of Earnings Management on Stock Return and the Role of Audit Quality as a Moderating Variable”. International Journal of Trade, Economics and Finance, 4 (2), 73-78. DOI: https://doi.org/10.7763/IJTEF.2013.V4.263.

Opler, T.C., and S. Titman. (1994). "Financial Distress and Corporate Performance”. The Journal of Finance, 49 (3), 1015-40. DOI: https://doi.org/10.1111/j.15406261.1994.tb00086.x.

Rezaei, F., and M. Roshani. (2012). "Efficient Or Opportunistic Earnings Management With Regards To The Role Of Firm Size And Corporate Governance Practices”. Interdisciplinary Journal of Contemporary Research in Business, 3 (9),1312-22.

Roychowdhury, S. (2006). “Earnings Management through Real Activities Manipulation”. Journal of Accounting and Economics. 42 (3), 335-70. DOI: https://doi.org/10.1016/j.jacceco.2006.01.002.

Scott, W.R. (2014) Financial Accounting Theory. 7th ed. New Jersey, USA: Prentice Hall.

Shirur, S. (2011). "Tunneling vs Agency Effect: A Case Study of Enron and Satyam”. Vikalpa: The Journal for Decision Makers, 36 (3), 9-26.

Siregar, S. V, and S. Utama. (2009). "Type of Earnings Management and the Effect of Ownership Structure, Firm Size, and Corporate-Governance Practices: Evidence from Indonesia”. International Journal of Accounting, 43 (1), 1-27.

Subramanyam, K.R. (1996). "The Pricing of Discretionary Accruals". Journal of Accounting and Economics, 22 (1-3), 249-81. DOI: https://doi.org/10.1016/S01654101(96)00434-X.

Suhardianto, N., and I. Harymawan. (2011). “A Decade of Earnings Management Researches in Indonesia”. Asia Pacific Journal of Accounting and Finance, 2 (1), 90-119.

Tabassum, N., A. Kaleem, and M.S. Nazir. (2015). "Real Earnings Management and Future Performance”. Global Business Review, 16 (1), 21-34. DOI: https://doi.org/10.1177/0972150914553505.

Tangjitprom, N. (2012). Earnings Management and Firm Value: The Role of Investor 
Protection and Corporate Governance. Working Paper. National Institute of Development Administration, Thailand.

United States Agency for International Development. (2013). Impact of ASEAN Capital Market Integration on Indonesia's Capital Market and Economy. USA:USAID.

Vorst, P. (2016). "Real Earnings Management and Long-Term Operating Performance: The Role of Reversals in Discretionary Investment Cuts". The Accounting Review, 91 (4), 1219-56. DOI: https://doi.org/10.2308/accr-51281.

Zang, A.Y. (2012). "Evidence on the Trade-Off between Real Activities Manipulation and Accrual-Based Earnings Management”. The Accounting Review, 87 (2), 675-703. DOI: https://doi.org/10.2308/accr-10196. 